\title{
The Problems of Furniture Sector and Suggestions for Solutions (A Case Study of Van)
}

\author{
Göksel ULAY* \\ Van Yuzuncu Yil University, Van Vocational School, Program of Furniture and Decoration, Van-Tuşba, 65040, Turkey
}

How to cite: Ulay, G. (2020). The Problems of Furniture Sector and Suggestions for Solutions (A Case Study of Van). J. Anatolian Env. and Anim. Sciences, 5(5), 849-857.

Atıf yapmak için: Ulay, G. (2020). Mobilya Sektörünün Sorunları ve Çözüm Önerileri (Van İli Örneği). Anadolu Çev. ve Hay. Dergisi, 5(5), 849-857.

\section{(iD: https://orcid.org/0000-0003-4080-8816}

Abstract: This study was carried out in order to determine the current situation and the problems faced by the enterprises operating in the Furniture and Carpenters Industrial Site in the city center of Van. For this purpose, 71 businesses were randomly selected from the businesses in Van furniture and carpenters industrial site. Businesses were visited and a questionnaire consisting of 12 questions was applied using face-to-face question-answer technique. With the questionnaire, data on the defining information of the enterprises such as the establishment date, number of employees and education status, production type, machines types, sales and order method, problems experienced and supports received were collected. As a result; the problems identified by the enterprises are respectively, the use of low technology machinery $(93 \%)$, website not having $(85.9 \%)$, insufficient vocational training (81.9\%), capital insufficiency (69\%), insufficient demand $(49.3 \%)$, transportation $(46.5 \%)$, workplace rent $(45.1 \%)$, raw material $(39.4 \%)$. In addition, it is determined that the average operating time of the enterprises is 26 years and the average working personnel is 3.1 people. Recommendations on consultancy services, cooperation with vocational training institutions and increasing the level of technology use were included for the furniture businesses within the scope of the research.

Keywords: Enterprises, Furniture, Production, Van, Woodwoorking.

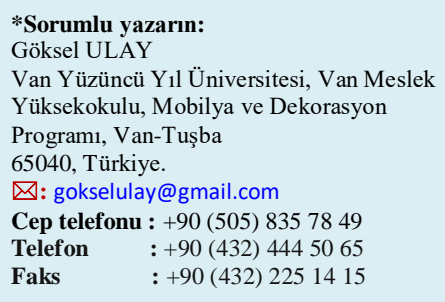

\section{Mobilya Sektörünün Sorunları ve Çözüm Önerileri \\ Mobilya Sektörünün Sorunları ve Çözừm Onerileri
(Van İli Örneği)}

Öz: Bu çalışma Van il merkezinde bulunan Mobilyacılar Sanayi Sitesi'nde faaliyet gösteren işletmelerin mevcut durumunu ve yaşadığı sorunları belirlemek amacıyla yapılmıştır. Bu amaçla Van mobilyacılar ve marangozlar sanayi sitesindeki işletmelerden rastgele 71 işletme seçilmiştir. İşletmeler ziyaret edilmiş ve yüz yüze soru-cevap tekniği kullanılarak 12 sorudan oluşan anket uygulanmıştır. Anket ile işletmelere ait kuruluş tarihi, çalışan sayısı ve eğitim durumu, üretim türü, mevcut makineler, satış yöntemi, yaşanan sorunlar ve alınan destekler gibi işletmeyi tanımlayıcı bilgilere iliş̧in veriler toplanmıştır. Sonuç olarak; işletmelere ait tespit edilen problemler sırasıyla, düşük teknolojili makine kullanımı (\% 93), web sitesine sahip olmamak (\% $85,9)$, mesleki eğitimi yetersiz personel $(\% 81,9)$, sermaye yetersizliği $(\% 69)$, talep yetersizliği $(\% 49,3)$, ulaşım (\% 46,5), işyeri kirası (\% 45,1), hammadde $(\% 39,4)$ ile ilgili olduğu tespit edilmiştir. Ayrıca işletmelerin ortalama faaliyet süresi 26 yıl ve işletme başına düşen ortalama personel sayısı 3,1 kişi olduğu belirlenmiştir. Araştırma kapsamındaki mobilya işletmelerine yönelik olarak danışmanlık hizmeti, mesleki eğitim kurumları ve diğer ilgili kurumlar ile iş birliği ve teknoloji kullanım düzeyinin artırılması konusunda önerilere yer verilmiştir.

Anahtar kelimeler: Ağaç ișleri, İșletme, Mobilya, Üretim, Van. 


\section{INTRODUCTION}

Furniture, which has always been a valuable item for people in the historical process, can generally be defined as equipment that meets needs such as resting, storage, and sitting (Ulay, 2011). Furniture is used in different geographical cultures of the world for purposes such as sitting, storage and display. Today, due to the increasing demand for furniture products, the level of technology usage in production processes has increased. With the creation of technological production processes, the furniture industry has become one of the world's advanced industries. Turkey, as the location for the furniture production facilities in terms of access to the necessary supply of raw materials is more advantageous as compared to other countries (Yegin, 2020).

Turkey in the furniture industry; It is traditionally thought to operate in the national and even local market with low technology, insufficient capital, labor intensive and expensive inputs. In fact, Turkey recently the furniture industry is undergoing a rapid technological transformation (Agras and Korkmaz, 2020) and compared to the past is transformed into more knowledge and capitalintensive fashion industry (TOBB, 2017). The most important factor behind this transformation is the competitiveness of the furniture industry and the rapid globalization process (Gurpinar and Barca, 2007). Furniture product is a typical example of global products that naturally comply with the requirements of international trade with their features such as fulfilling their basic functions and high design input (Yeniceri, 2005). Turkey's economy, producing value-added products and a significant number of jobs created (Okan, 2013), but also in the foreign trade surplus furniture industry has a special position in the economy.

However, the furniture industry in Turkey; lack of design (Karagoz and Sevim Korkut, 2017; Gurpinar and Doven, 2007), funding shortage (Akyuz et al., 2020; Malkocoglu et al. 2015; Serin and Sahin; 2020), lack of qualified personnel (Ulay, 2011; Ulay 2015; Ulay 2020), raw material and branding (Demirci, 2005), low technology usage level (Gurpinar and Doven, 2007), management deficiencies (Gurpinar and Doven, 2007), inadequate promotion and marketing (Coskun, 2019; Ustuner, 2010). It has been shown in many researches and sector reports in the literature that it has very important problems.

In general, in particular the problems of Turkey's Van furniture industry and is thought to be similar advantages. The province of Van has borders with Agrı in the north, Bitlis and Siirt in the west, Iran in the east and Sirnak and Hakkari in the south. Neighboring provinces are behind Van province in terms of production and infrastructure and at the same time have a market position (Ulay, 2020a). Van province of Turkey, with a total of 1.136.757 people in 2019 in terms of population is the 19th most populous province among 81 provinces (TUIK, 2019). The fact that the city population is over 1 million shows the importance of the need and production amount related to furniture consumption. Sub-Industry Fields of Activity Operating in the TRB2 Region The localization values (LQ) of furniture manufacturing in the years 20092014 are 0.25 (Deliktas and Celik, 2019). Considering the potential and numbers of furniture manufacturers in Van, no scientific research was found, except for the report prepared by DAKA (2017) for the furniture manufacturing sector. Considering the furniture production potential in the TRB2 Region of Van province and the surrounding provinces, scientific research on the furniture sector is of great importance.

According to Arslan (2018), there is also a lack of awareness in the furniture sector regarding the necessity of production at the quality standards required to increase the sales amount and profit of the goods produced in TRB2 in domestic and foreign markets. In the few studies conducted on enterprises in the province of Van, it was emphasized that SMEs do not receive support from professional companies when making investment decisions and that businesses need to develop ways to benefit from external resources in order to become more efficient and healthy (Kilicli, 2016; Kilicli and Aygun, 2018).

The aim of this study is; to determine the current structure and problems of small-scale furniture enterprises (SMEs) operating in the province of Van through the sample. As a result, in particular in Van province and its surroundings, usually the small-scale furniture business in a very important furniture manufacturing industry for Turkey's manufacturing industry (SMEs) to contribute to the development and be a pioneer for a more comprehensive future studies.

Turkey Furniture Industry: Turkey's furniture industry, mainly small-scale, which lack employees and exports by traditional methods consist of business owners the flexibility capabilities (BAKKA, 2012; Demirci, 2005; IMG, 2020; Sogutlu and Eroglu, 2009; Malkocoglu et al., 2013; TOBB, 2017). Furniture exporting countries in the world ranking of 11th. and that Turkey continued to rise in 2017 for 2.360 .407 million dollars, 2.686 .740 million dollars in 2018, while in 2019 has made exports of 3.055.447 million dollars. With this figure, it has $1.6 \%$ of the world furniture export market (IMG, 2020). Turkey Furniture employment of the industry is the most intense first 10 cities, respectively, Istanbul, Bursa, Kayseri, Ankara, Izmir, Kocaeli, Antalya, Duzce, Sakarya and Mersin (Karagoz and Sevim Korkut, 2017). 
When examined compulsorily insured employment figures registered a total of 14.314.313 million people are working in Turkey and their 154.829 people work in the field of manufacturing of furniture and constitute $1.08 \%$ of the total number of insured employees (SGK, 2019). The number of registered workplaces operating in the field of furniture manufacturing is 21.758 . The total number of registered businesses producing wood, wood products and mushrooms is 10.161 and 60.456 insured people are employed in this sector (SGK, 2019).

When analyzed according to the number of employees of enterprises scale furniture manufacturing sector in Turkey, $86.6 \%$ of $1-9$ people working, $81.1 \%$ of 1-6 people working, while $65.2 \%$ which runs between $1-3$ people consists of businesses (SGK, 2019).

The furniture industry has some vulnerabilities to future uncertainties and to improve its position; It is stated that improvement should be made by focusing on concepts such as job satisfaction and productivity (Yapar, 2005) and strategic management (Yegin, 2020). Turkey's furniture industry; strategic management, quality control, export, research, design and university\&industry cooperation (Ulay and Çakicier 2020) and the industrial estates of concepts such as discussion and adoption in business scale and is of great importance for the future of the industry.

Van Province Furniture Industry and Its Importance: Van province of Turkey's poorest provinces to TRB2 maintainde in the classification and socioeconomic development index (SEDI) ranks 75th in the ranking of 81 cities (SEDI, 2013). It is important to identify potential competitive sides and advantage by analyzing the existing sectors in the TRB2 region (Deliktas and Cekil, 2019).

According to the data of the Turkey Social Security Institution (SGK) in 2019, the total number of registered workplaces in the province of Van is 9440 and the total number of employees with compulsory SGK is 94.043 (SGK, 2019). It has been determined that there are 41 workplaces producing furniture with 31 activity codes and a total of 166 people work in these enterprises with insurance (SSI, 2019). A total of 117 people work in 36 workplaces registered in Wood, Wood Products and Mushroom Production with 16 activity codes, which is another business line where wood material is used as raw material (SGK, 2019).

According to DAKA (2017), it has been reported that there are 350 furniture manufacturers operating in Van registered to Van Chamber of Commerce and Industry and the current situation research of the sector covering 199 of these enterprises has been conducted. Similar to the general problem of the furniture industry in Turkey; in a different study in which all enterprises were included in the scope of the study, regardless of the scale, financial difficulties, lack of raw materials, insufficient demand, energy prices (Malkocoglu et al., 2015), unfair competition, raw materials, lack of capital, financing (Kilicli, 2016), technology used We are faced with low capacity utilization levels and a shortage of qualified personnel (Demirci, 2005; Ulay, 2011).

There is no scientific research other than the study prepared by DAKA (2017) for the Van furniture industry. The deficiency in this area should be filled with different studies. It has been reported that the furniture sector should be handled with a holistic perspective, taking into account the R\&D and innovation capability, product quality, taxes and incentives, informality, demand and similar problems (DAKA, 2017).

\section{MATERIALS AND METHODS}

In the first phase of the research, the carpenter and furniture industry site in the center of Tusba district of Van province was visited and the current situation of the industrial site was observed physically. 71 businesses registered in Van Chamber of Tradesmen and Craftsmen and Chamber of Furniture and Carpenters, randomly selected among the enterprises operating in the industrial site were included in the study.

Research Approach: The business scale classification determined by TUIK and operating in the Carpenter and Furniture Manufacturers Industrial Site located in the city center of Van is based on the number of employed personnel in Table 1.

Table 1. Enterprise size according to the number of employees (Ustuner, 2010).

\begin{tabular}{ll}
\hline Number of employees & Business size \\
\hline $1-9$ & Micro-scale business \\
$10-49$ & Small-scale business \\
$50-99$ & Medium-scale business \\
100 and above & Large-scale business \\
\hline
\end{tabular}

Method: The questionnaire consisting of 14 questions defining the basic information and current problems of the enterprises producing furniture, wooden doors and windows operating in the industrial site was applied using the face-to-face interview technique.

The questionnaires were applied to the responsible employee and / or business owner at the time of the visit. Considering that the research population is approximately $\mathrm{N}=200$ businesses, a sample group was formed in the study due to its size. It was calculated that $\mathrm{n}$ $=54$ using the formula below. In the literature, 30 or more sampling diameters (n) are considered sufficient for the sampling section to be normal (web-1, 2020). For this reason, 71 enterprises were investigated by increasing the sample diameter above 54 as much as possible $(n>30)$. Thus, the results to be obtained were tried to be more 
inclusive and reliable (Sogutlu and Eroglu, 2008; Malkocoglu et al., 2013; 2015).

In the survey application, the sample size (n) was calculated from below equation (Cil, 2000; Malkocoglu et al., 2013).

$n=\frac{Z^{2} \times N \times P \times Q}{N \times D^{2}+Z^{2} \times P \times Q}$

$\mathrm{Z}=$ Confidence Coefficient (1.96 was taken for $95 \%$ confidence), $\mathrm{N}=$ Large mass size, $\mathrm{P}=$ Probability of the property to be measured in the main mass $(95 \%), \mathrm{Q}=$ The probability of the feature to be measured is not found in the main mass $(5 \%), \mathrm{Q}=1-\mathrm{P}$ and $\mathrm{D}=$ indicate the accepted sampling error (10\%) (Malkocoglu et al., 2013). Data entries of the survey results were analyzed using MS Excel program. Tables were created by calculating the frequency percentages $(\%)$ of the information provided by the enterprises to the surveys, and the data were discussed and evaluated.

\section{RESULTS}

Within the scope of this research, the answers given by the enterprises to the questionnaire consisting of 14 questions prepared by the researcher are evaluated and given in tables in this section.

The average number of personnel in the enterprises participating in the survey was determined as 3.1 people.

It was determined that the operating years (age of the enterprise) of 71 enterprises within the scope of the research are 26 years on average.

The data on the education status of the personnel working in the enterprise are given in Table 2.

Table 2. Education status of employees.

\begin{tabular}{lcc}
\hline Graduation degree & F & \% \\
\hline University & 16 & 7,2 \\
Vocational High School & 25 & 11,3 \\
High School & 55 & 24,9 \\
Primary School & 126 & 57,0 \\
*F: Frequency & &
\end{tabular}

According to Table 2, $7.24 \%$ of the employed personnel are university graduates, $11.31 \%$ vocational high school graduates, $24.89 \%$ high school graduates and $57.01 \%$ primary education graduates. The product groups that businesses produce are given in Table 3 .

Table 3. Production types of enterprises.

\begin{tabular}{lll}
\hline Product Types & F & \% \\
\hline Furniture & 62 & 87,3 \\
Woodworking & 41 & 57,8 \\
Decoration & 49 & 69,0 \\
Other & 15 & 21,1 \\
\hline
\end{tabular}

According to Table 3, $87.3 \%$ of the enterprises produce furniture manufacturing, $57.8 \%$ woodworking (doors and windows etc.), 69\% decoration and $21.1 \%$ other types of products. It has emerged that some of the businesses have a flexible structure that they can do both furniture and joinery or decoration works together. The data of the machine types in the enterprise are given in Table 4.

Table 4. Machine types found in the enterprises.

\begin{tabular}{cccccc}
\hline Machine types & F & \% & Machine types & F & \% \\
\hline CNC & 5 & 7,0 & Thickness & 47 & 66,2 \\
Edgebant & 36 & 50,7 & Band-saw & 29 & 85,0 \\
Circular-saw & 61 & 85,9 & Drilling & 43 & 60,5 \\
Plane & 47 & 66,2 & Milling & 46 & 64,8 \\
Other type & 45 & 63,4 & & & \\
\hline
\end{tabular}

According to Table 5, 90.1\% of the enterprises ordered by phone, $12.7 \%$ from the internet, $5.6 \%$ from the showroom, $97.2 \%$ from acquaintances, $90.1 \%$ by coming to the workshop it was determined that he ordered.

In this research, it was determined that there are businesses that use more than one and different order taking methods. Data on the most common problems faced by businesses are given in Table 6 .

Table 6. The most common problems in enterprises.

\begin{tabular}{llllll}
\hline Problem type & F & \% & Problem type & F & \% \\
\hline About personnel & 26 & 36,6 & Rent & 32 & 45,1 \\
Lack of demand & 35 & 49,3 & Transport & 33 & 46,5 \\
Raw material & 28 & 39,4 & Workshop area & 27 & 38,0 \\
Lack of capital & 49 & 69,0 & Other & 18 & 25,4 \\
\hline
\end{tabular}

According to the data in Table 6, business problems; $36.6 \%$ personnel, $49.3 \%$ lack of demand, $9.4 \%$ raw material, $69 \%$ lack of capital, $45.1 \%$ rent, $46.4 \%$ transportation, $38 \%$ one of them is due to workshop area and $25.3 \%$ from other reasons.

Among the other reasons reported as; insurance premiums, lack of qualified apprentices and journeymen, advertising, promotions, insufficient support and incentives. The data regarding the training requests for the employees of the enterprises are given in Table 7.

Table 7. The status of requesting free training for employees in the business.

\begin{tabular}{llrlll}
\hline Sucject training & F & \% & Subject training & F & \% \\
\hline Furniture desing & 35 & 49,3 & Oparetor and maintenance & 29 & 40,9 \\
AutoCAD & 31 & 43,7 & Planning/organization & 31 & 43,7 \\
Computer & 26 & 36,3 & Work safety & 39 & 54,9 \\
CNC Machine & 30 & 42,3 & & & \\
\hline
\end{tabular}

Training subjects requested by enterprises according to Table $7 ; 49.3 \%$ furniture design, $43.7 \%$ use AutoCAD, $36.3 \%$ computer use, $42.3 \%$ use CNC, $40.9 \%$ operator and maintenance, $43.7 \%$ planning and organization and $54.9 \%$ work safety. The data on the ownership of a website by the enterprises are given in Table 8 . 
Table 8. The state of ownership of the website of enterprises.

\begin{tabular}{lll}
\hline Do you website of enterprises ? & F & $\%$ \\
\hline Yes & 10 & 14,1 \\
No & 61 & 85,9 \\
\hline
\end{tabular}

According to Table 8 , while $14.1 \%$ of the enterprises have a website, it has been determined that $85.9 \%$ of the enterprises do not have a website. The reasons why businesses do not have a website are given in Table 9.

Table 9. The reason for the lack of a web page belonging to businesses.

\begin{tabular}{lll}
\hline The reason for lack of web page & F & \% \\
\hline Economic reasons & 28 & 39,4 \\
Not needing & 22 & 31,0 \\
Lack of time & 7 & 9,9 \\
Not to find opportunities & 12 & 16,9 \\
Lack of information & 9 & 12,7 \\
\hline
\end{tabular}

According to Table 9, enterprises; It was determined that $39.4 \%$ due to economic reasons, $31 \%$ due to not needing, $9.9 \%$ to lack of time, $16.9 \%$ not to find opportunities and $12.7 \%$ due to lack of information. Cooperation status of enterprises with any educational institution is given in Table 10 .

Table 10. The cooperation of enterprises with any educational.

\begin{tabular}{lcr}
\hline Type of institution & F & \% \\
\hline Vocational High School & 15 & 21,1 \\
University & 11 & 15,5 \\
Public Education Center & 2 & 2,8 \\
Dont Cooperation & 43 & 60,6 \\
\hline
\end{tabular}

According to Table 10, enterprises; It was determined that $21.1 \%$ cooperate with vocational high schools, $15.5 \%$ with the university, $2.8 \%$ with the public education center, but $60.6 \%$ of the enterprises do not cooperate with any institution. The data on whether the business receives financial support from any institution or not is given in Table 11 .

Table 11. Whether businesses receive support from any institution.

\begin{tabular}{lll}
\hline Support status & F & $\%$ \\
\hline Yes & 16 & 22,5 \\
No & 55 & 77,5 \\
\hline
\end{tabular}

According to Table 11, enterprises; It was determined that $22.5 \%$ received KOSGEB project support and $77.5 \%$ did not receive support from any institution. Data pertaining to the need for social equipment required for enterprise employees are given in Table 12.

Table 12. The social facilities required by employees working in enterprises.

\begin{tabular}{lcc}
\hline Types of social facilities & F & \% \\
\hline Banyo-WC & 45 & 63,4 \\
Restaurant & 46 & 64,8 \\
Cafe-tee home & 53 & 74,6 \\
Other & 41 & 57,8 \\
\hline
\end{tabular}

According to Table 12, employees; It was determined that $74.6 \%$ needed cafe-tea house, $64.8 \%$ restaurant, $63.3 \%$ bathroom and $\mathrm{WC}, 57.8 \%$ other social facilities in the industrial site. The demands of the working personnel from the relevant institution for the industrial site are given in Table 13.

Table 13. The demand of working personnel from the relevant institution.

\begin{tabular}{llllll}
\hline Demand subject & F & \% & Demand subject & F & \% \\
\hline Health center & 21 & 29,6 & About financial support & 20 & 28,2 \\
Moque & 7 & 9,9 & Demand and promotion & 15 & 21,1 \\
Park & 6 & 8,5 & Fire station & 2 & 2,8 \\
Transportaion & 10 & 14,1 & New workshop area & 5 & 7,0 \\
\hline
\end{tabular}

As the general demand of enterprises in Table 13; health center $29.6 \%$, information on financial support $28.2 \%$, demand and promotion $21.1 \%$, transportation $14.1 \%$, mosque $9.9 \%$, park $8.5 \%$, new workshop area $7 \%$, fire-station $2.8 \%$. The data regarding the need for showrooms where the enterprises will display their products are given in Table 14.

Table 14. The need for a showroom for businesses to display products.

\begin{tabular}{lll}
\hline Do you need showroom ? & F & \% \\
\hline Yes & 40 & 56,3 \\
No & 19 & 26,8 \\
\hline
\end{tabular}

According to Table 14, the enterprises; $56.3 \%$ stated that there is a need for a common showroom within the industrial site, $26.8 \%$ stated that there is no need for a showroom.

\section{DISCUSSION and CONCLUSION}

Within the scope of the research, it was determined that the activity year (age of the enterprise) of 71 furniture manufacturing enterprises in the city center of Van is 26 years on average. In the literature, according to Kilicli and Aygun (2018), 37\% of the 54 enterprises in the Van Organized Industrial Zone (OIZ) have an average of 16 years and above. According to DAKA (2017), 56.8\% of the enterprises in the Van furniture industry have been operating for 10 years or more, and $28.1 \%$ have been operating for 6-10 years. It can be thought that enterprises can have their experience in the sector and the ability to survive against crises at different times. The relationship between the approaches of the enterprises that have adopted the traditional production and management style against innovations and change and their activity durations can be examined with different studies.

According to the education level of the working personnel; it was determined that they graduated from primary education $(57 \%)$, high school $(24.9 \%)$, vocational high school (11.3\%) and university (7.2\%). It is thought that the education level and type of training of the employees should be suitable for manufacturing in the technical field such as furniture and decoration (table 2). 
However, it was determined that approximately $82 \%$ of the personnel did not receive vocational training. In the literature in Turkey furniture industry professional trained to be in need of qualified personnel (BAKKA, 2012; Coskun, 2019; DAKA, 2017; Demirci, 2005; Gorguc, 2008; Gurleyen et al., 2010; Malkocoglu et al., 2013; TOBB, 2017; Ulay, 2011; Ulay, 2020) and 68\% of enterprises do not employ training staff (Gurleyen et al., 2010). The findings of the study are consistent with the literature. The vocational and technical training needs of the personnel can be met through in-service or vocational training institutions.

According to the findings, the majority of the enterprises produce furniture $(87.3 \%)$, decoration $(69 \%)$ and woodwork $(57.8 \%)$ and other $(21.1 \%)$ products (Table 3 ). It has been reported that the majority of the enterprises are manufacturing furniture and decoration, and more than half of them produce woodwork and related production.

It is understood that businesses keep their product range wide rather than specializing in certain areas. This situation is considered as an indicator of the flexibility characteristics of SMEs. Data consistent with the literature (DAKA, 2017; Malkocoglu et al., 2017).

The average number of employees for 71 workplaces in the Van furniture sector is 3.1 people. It is included in the micro enterprise definition made by TUIK. SGK (2019) argues that employ 1-3 people, $65.2 \%$ of the furniture business in Turkey, is made up of enterprises which employ staff while $86.6 \%$ between 1-9 people. It has been determined that Kilicli and Aygun (2018) constitute $9.3 \%$ (5) of the 54 enterprises in Van OIZ and the rate of those with less than 10 employees is $29.6 \%$ for all enterprises. According to DAKA (2017), 98.5\% (196) of 199 furniture businesses in Van province are micro-scale and $1.5 \%$ are small-scale enterprises. The results of the study are compatible with the literature. On the other hand, it is thought that the high number of furniture enterprises in the province of Van, the low number of employees, working with low capacity and the increase in the number of enterprises due to unplanned expansion in the sector. Investment consultancy can be recommended to remedy the deficiency in this matter.

When the data on the machine capacity of the enterprises are examined; It has been determined that $93 \%$ of the enterprises, that is almost all of them, use conventional type machines. According to DAKA (2017) in the literature, it is reported that $90 \%$ of the enterprises use traditional machinery. It is thought that the technological machine usage levels of the enterprises are low and accordingly there is a deficiency in meeting their demands and customer satisfaction.

Businesses demand from customers; It was determined that $97.2 \%$ was done by acquaintances, $90.1 \%$ by coming to the workshop, $90.1 \%$ by phone, $12.7 \%$ by internet and $5.6 \%$ by showroom (Table 5). It is thought that traditional methods are widely used for businesses to gain new business and customers, which may cause a lack of demand and a decrease in sales. Similar problems have been reported in furniture businesses in different provinces in the literature. Coskun (2019) stated that foreign language web pages of businesses can increase their sales and export opportunities. Ustuner (2010) stated that the activities they did not allocate resources for promotion and marketing were insufficient.

Common problems in businesses; lack of capital, insufficient demand, lack of transportation, rent, raw materials, workshop area, and qualified personnel (Table $6)$. The results of the study were similar to the results of the study in the literature (Akyuz et al., 2020; DAKA; 2017; Malkocoglu et al., 2015; Ustuner, 2010; Serin and Sahin, 2020; Kilicli, 2016) for reasons such as lack of capital, shortage of raw materials and financing.

It is recommended to benefit from $R \& D$ and incentive supports, focusing on products with specific features (BAKKA, 2012) and producing innovative products.

According to Table 8, it was determined that $85.9 \%$ of the enterprises do not have a website where they can display their products. Businesses are considered to be insufficient in introducing their products and services to the market. According to DAKA (2017) in the literature, the promotional and marketing activities of most furniture companies in Van are carried out at a primitive level; According to Coskun (2019), it has been reported that businesses that do not have websites in a foreign language, not promoting their target markets negatively affect their export potential. According to BAKKA (2012), it has been reported that enterprises cannot carry out promotional and marketing activities and the content of those who have a web page is insufficient. There are studies stating that there is a lack of publicity and image in the furniture sector (BAKKA, 2012; Ustuner, 2010; TOBB, 2017). For this reason, it is thought that small and medium-sized enterprises should improve themselves in advertising and promotion, allocate a budget for these issues, and receive professional support for promotion and digital marketing activities.

According to Table 9, 39.4\% of the enterprises are due to economic reasons, $31 \%$ due to not needing, $9.9 \%$ due to lack of time, $16.9 \%$ not to find opportunities and $12.7 \%$ due to lack of information. It has been determined that they do not have a website. It has been reported in the literature that advertising and marketing activities are not carried out because the lack of qualified personnel to prepare web pages of furniture businesses and their costs are avoided (BAKKA, 2012; Coskun, 2019; Ustuner, 
2010). While the lack of a web page where businesses can display their products causes a lack of promotion, this may result in a lack of demand.

According to Table 10, $21.1 \%$ of the enterprises cooperate with a vocational high school, $15.5 \%$ with a university and $2.8 \%$ with a state education center. According to DAKA (2017), organizations that produce information with clustering, non-governmental organizations, suppliers and educational institutions have stated that they should be in interaction. According to TOBB (2017), the subject of qualified labor as school, employee, boss/employer should be considered together and sustainable solutions should be produced. Aksin et al. (2020) emphasizes the cooperation between universities and enterprises with high infrastructure and technology in order to adapt to the developments in our rapidly developing age. It has been reported that some enterprises have protocols for the admission of intern students to vocational high schools. According to Ulay (2020), it has been reported that as an academician observation, furniture and decoration students who graduated from vocational school are unwilling to work in this sector. It has been observed that many businesses do not cooperate with any educational institution. Turkey businesses operating in the furniture industry and one of the biggest shortcomings of professional training institutions of the co-culture is unsettled. This situation is thought to be one of the most important factors in development.

According to Table 11, it was determined that $22.5 \%$ of the enterprises received support from KOSGEB, while $77.5 \%$ did not receive support from any institution. Results of studies in the literature; In the study conducted by DAKA (2017) for Van furniture businesses, approximately 29\% of 199 businesses benefited from KOSGEP and DAKA supports; According to Kilicli and Aygun (2018), it is compatible with the information that SMEs in Van OIZ benefit the most from KOSGEB and Halk Bank as credit source after commercial banks. However, despite these results, it was evaluated that many enterprises had capital shortages and did not receive any support and could not meet the necessary conditions for the support provided (Ulayi 2020a). Reducing bureaucratic difficulties and sustainability should be taken into consideration in the conditions sought in enterprises that will receive support. In support applications, free consultancy services can be created for enterprises within the scope of university-industry cooperation (Ulay and Cakicier, 2020).

According to Table 12, it has been determined that $74.6 \%$ of them need social facilities such as cafe-tee house, $64.7 \%$ restaurants, $63.3 \%$ bathrooms and wc. Sögütlü and Eroglu (2008) found that employees in furniture businesses do not have sufficient knowledge about the use of physical equipment and infrastructure. It is also found in the literature that meeting the physical needs of the employees will provide employee motivation and job satisfaction and affect productivity (Yapar, 2005). Ensuring employee satisfaction is considered necessary and beneficial for businesses and the social environment.

In Table 13, as the general demand of the enterprises; health center, qualified personnel, lack of demand, advertisement and promotion, transportation facilities, mosque, park, fire station. It is thought that deficiencies in demand issues may negatively affect employee motivation and job satisfaction levels. According to Yapar (2005) in the literature, he reported that employee motivation has an effect on work efficiency.

According to Table 14, the enterprises $56.3 \%$ of them stated that a common showroom is needed in the industrial site, $26.8 \%$ stated that there is no need. It is understood from these results that businesses lack awareness about sales and marketing. Electronic Commerce (E-Commerce) in the literature can be used in the furniture industry as in almost every field (Kurt, 2019). Businesses with low demand and difficulties in advertising (Ustuner, 2010) should be aware of up-to-date solution opportunities such as showrooms, e-showrooms and efairs, online catalogs, furniture stores, and recognize effective methods of delivering their products to customers. Cluster models such as industrial sites are thought to have shortcomings in sales and marketing by store when it comes to reaching customers. Convenience in product sales and an increase in demands can be achieved when businesses come together and create a common showroom or electronic commerce platform / page.

As a result, this research on the Van furniture industry is very important for the development of the furniture industry in terms of increasing community employment and welfare in the province and region. Conducting research that reveals the results of the cooperation between qualified personnel and institutions for the furniture sector and sharing the results with the sector will raise awareness and encourage the parties. Knowing the strengths and weaknesses of the Van furniture industry, the number of businesses that will create innovation should be increased. New research can be conducted on strategically important issues such as technology usage levels to improve institutionalization and branding skills.

\section{SUGGESTIONS}

- Training in the field of furniture manufacturing should be given to those who have not received vocational training $(81.9 \%)$ in cooperation with vocational training institutions. 
- The use of machinery with CNC technology (7\%), which is inadequate, is increased and the level of technology usage in production is improved.

- Businesses that do not have a website (85.9\%), insufficient demand $(49.3 \%)$ and lack of promotion / advertising $(21.1 \%)$ should update their ordering patterns and provide accessibility with the website.

- $\quad$ The most demanded training subjects are work safety (54.9\%), furniture design (49.3\%), Autocad and planning (43.7\%), CNC machine use (42.5\%), the institutions that provide relevant vocational training and training within the scope of the project.

- The website that cannot be made due to economic difficulties, raw material supply, rent, etc. For situations, initiatives can be taken to get support from KOSGEB, DAKA etc. institutions that provide financial support and loans.

- Another reason for insufficient demand may be insufficient quality level and customer satisfaction in products and services, so the quality level should be increased.

- Employees' physical and social needs such as tea houses and restaurants $(74.6 \%)$, bathroom-wc (63.4\%), healthcare station (29.6\%) should be met and employee satisfaction should be measured regularly.

- Enterprises that do not receive any support from any institution (77.5\%) should improve their ability to benefit from grant support. KOSGEB, DAKA, Van TSO etc. It is recommended to carry out studies in institutions to gain grant and fundraising skills to micro-enterprises.

\section{ACKNOWLEDGMENTS}

This study was presented in ORENKO 2020 and published Abstract book, held by Karadeniz Technical University, Trabzon.

\section{REFERENCES}

Akyuz, K. C., Yildirim, I., Hamzacebioglu, O., \& Ersen, N. (2020). Financing problems and solution suggestions of forest products industry enterprises located in Istanbul Ikitelli organized industrial zone. Artvin Coruh University Journal of Forestry Faculty, 21(2), 244-250.

Arslan, O. (2018). Creating an ecosystem for the sustainable development of prominent sectors in Mus province. Muğla Sitkı Koçman University Faculty of Economics and Administrative Sciences Journal of Economics and Management Research, 7(1), 114-166.

Askin, A., Cetin, F., \& Cabuk, Y. (2020). Evaluation of university-industry cooperation application in terms of furniture and decoration program graduates. Bartın Forestry Faculty Journal, 22(2), 1-1.

BAKKA. (2012). Western Black Sea Development Agency (BAKKA), TR81 Level2 furniture and forest products sector analysis report, Zonguldak, Turkey, pp: 233.

Cil, B., (2014). Statistics and numerical methods, $8^{\text {th }}$ edition, Detay Publishing, Ankara, Turkey, 189209.

Coskun, S., (2019). Increasing the export potential in the furniture industry: Inegol example. Bursa Uludağ University, Institute of Social Sciences. Unpublished Master's Thesis.

DAKA. (2017). Eastern Anatolia Development Agency (DAKA), Van furniture industry and the development of competitive cluster potential report, Van, Turkey, pp: 63.

Dalgakiran, A. B. \& Ozturkoglu, Y. (2017). Turkey scales for the furniture industry and association analysis. Business \& Management Studies: An International Journal, 5(1),147-161.

Deliktas, E \& Celik, N. (2019). Determination of Competitive Sectors in TRB2 Region. Izmir Katip Celebi University Journal of the Faculty of Economics and Administrative Sciences, 2(1), 2944.

Demirci, S. (2005). Problems and solutions of Turkey furniture industry, Polytechnic Journal, 8(4), 369379.

Gorguc, B.,(2009). Furniture industry and businessmen association, 2008 Furniture sector report, Journal of Furniture Decoration, 91, 96-104.

Gurleyen, L., Cakicier, N. \& Ulay, G., (2010). Investigation of in-service training in furniture sector, Journal of Furniture Decoration, 95,118138.

Gurpinar, K \& Doven, M. (2007). Analysis and evaluation of the competitive situation of the Turkish furniture industry from a strategic management perspective. Afyon Kocatepe University Journal of Economics and Administrative Sciences, 9(1),173-190.

Gurpinar, K. \& Barca, M. (2007). International competitiveness level and reasons of Turkish Furniture Industry. Eskişehir Osmangazi University Journal of Economic and Administrative Sciences, 2(2), 41-61.

IGM, (2020). T.C. Ministry of Trade, (Ihracat Genel Mudurlugu (IGM) / General Directorate of Export), Department of Mining, Metal and Forestry, Furniture SectorReport.https://ticaret.gov.tr/data/5b870001 3b8761450e18d7b/Mobilya\%20Sekt\%C3\%B6r \%20Raporu\%202020.pdf , Ankara, Turkey, (17/11/2020), pp.13.

Karagoz, T \& Sevim Korkut, D. (2017). Problems of the furniture industry and solutions (Kocaeli Province Case). Journal of Advanced Technology Sciences, 6(3), 85-92.

Kilicli, Y. \& Aygun, M., (2018). Financing problems of SMEs and solutions: A research on Van 
Organized Industrial Zone. Van Yüzüncü Yıl University Institute of Social Sciences Vankulu Journal of Social Research, 1, 135-152.

Kilicli, Y. (2016). Financing and marketing problems of SMEs and their solution suggestions: A research on Van Organized Industrial Zone, M.Sc. Thesis, Van Yuzuncu Yil University, Institute of Social Sciences. Van, Turkey.

Kurt, R. (2019). Evaluation of e-commerce in furniture sector with SWOT Analysis. Duzce University Journal of Science and Technology, 7(1), 616627.

Malkocoglu, A., Yayli, K., Yildirim, I. \& Ataseven, F. (2015). Turkey's furniture sector small and medium-sized businesses structural examination of the issues and solutions. Journal of SelcukTechnical, 14(2), 747-764.

Okan, T., (2013). Turkey Furniture sector competitiveness level of analysis. 2th.National Furniture Congress, 11-13 April 2013, Denizli, Turkey, 192-199.

SEDI, (2013). Socio-Economic Development Index Ranking of Provinces and Regions SEGE - 2011, General Directorate of Regional Development and Structural Adjustment, Ankara, Turkey, pp:70.

SGK. (2019). Social Security Institution/Sosyal Guvenlik Kurumu ( $S G K)$, Statistics, workplaces within the scope of Table 1.11-4 / a and distribution of compulsory insured by activity group (.xls), Ankara, Turkey, http://www.sgk.gov.tr/wps/portal/sgk/tr/calisan. (10/11/2020).

Sogutlu C. \& Eroglu F., (2008). Investigation of Physical Conditions of Furniture Businesses in Ankara, Polytechnic Journal, 11(4),373-378.

Sogutlu, C. \& Eroglu, F. (2009). Examining the factors affecting the export status of furniture companies in the sample of Ankara sites region. Polytechnic Journal, 12(2), 101-106.

TOBB. (2017). (Turkiye Odalar ve Borsalar Birligi/Turkey Union of Chambers and Commodity Exchanges),Turkey furniture products industry council report. Ankara, Turkey, pp.88.

TUIK. (2019). (Turkiye Istatistik Kurumu (TUIK)/Turkish Statistical Institute), Address Based Population Registration System Results in Turkey, 2019.
https://data.tuik.gov.tr/Bulten/Index?p=AdreseDayali-Nufus-Kayit-Sistemi-Sonuclari-201933705. (10 November 2020).

Ulay, G. (2020). Furniture decoration education in vocational high schools and examination of the personnel needs of the sector, Journal of Furniture and Wood Material Research (FURAJ), 3(2), 11-23.

Ulay, G. (2011). Examination of the furniture industry and qualified personnel employment, Jorunal of Furniture Decoration, 101,130-152.

Ulay, G. (2015). The importance of industrial internship in furniture education and an exemplary application. Journal of Selcuk Technical, (UMK-2015, Special Issue), 452-466.

Ulay, G. \& Cakicier N. (2020). Furniture manufacturing enterprises with a critical overview of the process of trying to develop University\&Industry Cooperation,6th International Furniture Congress, 2-5 November 2020, Trabzon-Turkey, pp: 1 .

Ulay, G. (2020a). The problems of furniture sector and suggestions for solutions (A Case Study of Van), International Forest Product CongressORENKO2020, 23-26 September 2020, Abstract Book, Trabzon-Turkey, pp:18.

Ustuner, A. I. (2010). Problems faced by furniture and decoration businesses in Ankara and solutions, Gazi University, Institute of Science, Unpublished M.Sc. Thesis, Ankara, Turkey.

Web-1, (2020). Bio statistics, sample size https://uroturk.org.tr/urolojiData/Uploads/files/ge lecek-akademisyen-1210/Sunum-9.pdf $(10 / 09 / 2020)$.

Yapar, T., (2005). The effect of motivation on work productivity, Istanbul University, Institute of Social Sciences, M.Sc. Thesis, Istanbul, Turkey.

Yegin, T. (2020). Strategic analysis: a research on furniture sector. International Journal of Management and Administration, 4(7),100-111.

Yeniceri, B., (2005). Turkey industry exports market research, Home and Office Furniture Industry External Market Research Report, IGEME Publications, Ankara, Turkey. 